\title{
Entomological Index and Home Environment Contribution to Dengue Hemorrhagic Fever in Mataram City, Indonesia
}

\author{
Tri B T Satoto1, Nur Alvira Pascawati2*, Tri Wibawa ${ }^{3}, \cdots$
}

\begin{abstract}
${ }^{1}$ Department of Parasitology, Faculty of Medicine, Gadjah Mada University, Yogyakarta, Indonesia
2Public Health Studies Program, Faculty of Health Science, Respati University, Yogyakarta, Indonesia

${ }^{3}$ Department of Microbiology, Faculty of Medicine, Gadjah Mada University, Yogyakarta, Indonesia
\end{abstract}

\begin{abstract}
Indonesia is a member of Southeast Asia Regional Office (SEARO) ranked the first in dengue hemorrhagic fever (DHF) problem based on incidence rate (IR) and case fatality rate (CFR). Several provinces in Indonesia experience an outbreak, one of which is the Mataram City in West Nusa Tenggara Province. Mataram City is an endemic area of DHF because the DHF cases are always found in three consecutive years with the number of cases that fluctuate and tend to increase. This study aimed to obtain factors that could be used to improve early warning systems in controlling DHF. This study used a case control design with a ratio of 1:1 to 180 households. The results showed that home environmental factors, such as no ceiling, indoor and outdoor temperature that had the potential for breeding places for mosquitoes, no wire net in ventilation, low lighting and high humidity, related to DHF transmission. Vector distibution with entomology index showed that the existence of larvae, eggs and mosquitoes played a role in dengue transmission. The dominant factors affecting the transmission of dengue in Mataram City are the condition of the ceiling and the existence of mosquito eggs in the house.
\end{abstract}

Keywords: dengue hemorrhagic fever, entomolgy index, home enviroment, Mataram

\section{Introduction}

Dengue hemorrhagic fever (DHF) has spread throughout the world including in the WHO region namely Pan American Health Organization (PAHO), Southeast Asia Regional Office (SEARO) and the Western Pacific Region (WPRO). ${ }^{1}$ Indonesia is a member of SEARO, which during 1990-2015 was ranked the first in DHF problems based on incidence rate (IR) and case fatality rate (CFR). ${ }^{2}$ In Indonesia, the incidence rate of 2016 DHF increased by 77.96/100,000 population compared to the previous year, e.g., $50.83 / 100,000$ population was still very far from the national target $<49 / 100,000$ population and several provinces in Indonesia experienced an outbreak. ${ }^{3}$ The Mataram City is an endemic area of dengue with the fluctuating number of the case because even though the incidence rate in Mataram is lower than the national target, the area has experienced an increase by up to $95.88 \%$ in the last two years, from IR $10.68 / 100,000$ in 2015 with CFR 0\%, to IR 20.92/100,000 residents with CFR $0.75 \%$ in 2016.4

Transmission of DHF occurs due to the presence of sufferers and carriers of the dengue virus. The current expansion of dengue shows multifactorial and may include virus evolution, climate change, and social factors such as urbanization, population growth and development, socio-economic, as well as global travel ${ }^{5}$ and population mobility caused a significant increase in dengue cases. ${ }^{6}$ Other influential factors are climate change, environmental changes and transmission of DHF cases that indicate spatial and temporal patterns. ${ }^{7}$ Prospective cohort studies show a correlation between the density of Aedes aegypti (Ae. aegypti) and the prevalence of dengue fever infection because vector density is associated with the tendency of mosquitoes to suck blood from humans. This condition increases contact between humans and mosquitoes, or the transmission of dengue virus is very easy; thus, the density of these vectors needs to be reduced as low as possible. 8 The results of the study in Banjarnegara District showed transovarial transmission with a frequency of $11.54 \%$ and larva free amount still below $95 \% .9$

Several studies showed that mosquito species that have habitat around the human environment with inadequate living conditions and sanitation are Ae. 
aegypti, Ae. albopictus and Culex quinguefasciatus. 10,11 Physical environmental factors are factors affecting the presence and level of Aedes larvae density such as light intensity, ventilation, drainage, and distance of buildings, ${ }^{12}$ but different results are expressed in studies in Yogyakarta and Mataram that humidity is the dominant factor associated with dengue transmission in children. ${ }^{13,14}$ A study in Kupang City explained that water use, wall construction, ventilation area and availability of clean water facilities were factors related to dengue cases. ${ }^{15}$ Water stored in containers for long periods, long rainfall during the rainy season, humidity and ambient temperature can increase the breeding of Ae. aegypti mosquitoes. ${ }^{16}$

The aim of this study would show that predictor variables such as entomological index (existence of larvae, density of larvae, existence of eggs inside, existence of eggs outside, and existence of adult mosquitoes) and home environment (floor, wall, ceiling, ventilation, temperature, light intensity, humidity) contribute to DHF in Mataram City. This factor has a non-homogeneous and unstable nature in distribution because it is related to the characteristics of society, thus complicating the assumption that epidemiological change as a single factor. Although physical environmental factors have a high complexity of vector distribution and incidence of dengue cases, but it can be a useful tool for the preparation of scenarios for prevention of local outbreaks of DHF. ${ }^{17}$ The results were beneficial in developing active surveillance model of DHF outbreak by the analysis of potential predictors, as well as in identifying high-risk areas for DHF outbreak, so that timely management can be achieved.

\section{Method}

The study was an observational study used case control design. The current study was conducted in the Subdictrict of Pagutan, West Pagutan and Salagalas, Mataram City from October 2019, during dry season. ${ }^{18}$ Study population selected were all the patients diagnosed with DHF based on data from Epidemiological Investigation with a number of samples using the Lameshow and Lwanga formulas for hypothesis test for two population proportions (two-sided test) study with ratio of 90 cases and 90 controls. Then, the total sample of the populations were 180 households. The sampling technique used proportionate stratified random sampling, with households in three sub-districts as samples. Determination of the number of samples for each head of sub-village with proportional composition was then taken by systematic random sampling. The case criterion was a patient diagnosed in the last three months. Frame sampling used medical records of DHF patients based on Epidemiological Investigation (Outbreak Investigation Form) and Early
Warning System scores used by hospital. The control criterion was the closest neighbor to the case by matching the case based on age, sex and living place within a maximum of 100 meters from the patient's home.

The types of data collected were home enviroment factors, such as the room temperature that has the potential to breeding places for mosquitoes and where mosquitoes lay eggs, the room air humidity $>60 \%$, home enviroment (floors and walls not waterproof, no ceiling or ceiling $<2.5 \mathrm{~m}$, wire-free ventilation and lighting $<60$ lux meters). The factors of existance and vector density based on entomology index were eggs, larvae and adult female mosquitoes. The types of instruments used are: aspirator backpack, lux meter, hygrometer, and carbondioxmeter that has been calibrated. Observation guidelines for identifying vector densities and container characteristics using vector data collection guidelines in the field compiled by National Institute of Health Research and Development, Indonesian Ministry of Health 2016. The measurement for mosquito egg density was carried out by spreading two ovitrap in each house with a total of 360 ovitraps in 180 houses.

Univariate analysis is presented in the frequency distribution values. Bivariate and multivariate analysis using simple and multiple logistic regression tests aimed at analyzing the factors associated with transmission of DHF which caused local outbreaks in Mataram City. The results of simple logistic regression analysis were used to select variables that met the criteria as candidates for the control model of local DHF outbreaks in Mataram City with $\mathrm{p}$-value $<0.250 .{ }^{19}$ The analysis was continued by multiple logistic regression tests with the backward method to find out the predictor variables in the physical environment and vector density associated with DHF transmission, the strength of the relationship between these variables and the model or formula for predicting dengue transmission in Mataram City. Model quality assessment was carried out to determine the discrimination value based on area under curve (AUC) with the receiver operating curve (ROC) method, whereas the model calibration using Hosmer and Lemeshow. The formula was stated to have good discrimination if the AUC value was closer to number 1 and was said to have a good calibration if it has a value of $p$-value $>0.050$ on Hosmer and Lameshow. ${ }^{20}$ This study is part of a study approved for ethics by the Faculty of Health Science, Respati University of Yogyakarta, with Protocol Number: 167.1/UNRIYO/PL/VII/2018 on July 2018.

\section{Results}

The present study was conducted in the Subdistricts of Pagutan, West Pagutan and Salagalas, Mataram, West Nusa Tenggara. These three locations have differences with other subdistricts in Mataram City, because it is 
inhabited by people coming from affects culture in Indonesia, it is included in the category of high-endemic dengue and stated to be a local outbreak of DHF in 20162017. Most cases in Mataram City have a record of having been diagnosed with DHF once (96.7\%), male and female patients have almost the same proportion, aged 5-11 years with an education level graduating from elementary school $(25.6 \%)$ and preschoolers $(33.3 \%)$.

Observation and measurement of house enviroment including flooring, wall, door, ceiling, ventilation, temperature, humidity and lighting were made to obtain potential factors that favor mosquito breeding and dengue virus transmission in Mataram City are presented in Table 1. Highest wind velocities were recorded during August through December.

Table 1 shows that physical environmental factor like the condition of a house with no ceiling or with a height of $<2.5 \mathrm{~m}$ is related to dengue transmission and raises the risk of a local outbreak by 16 times with $95 \% \mathrm{CI}=$ 7.237 - 36.769. Indoor and outdoor temperature of the house at $25-30^{\circ} \mathrm{C}$ is related to dengue transmission and raises the risk of a local outbreak of 2 until 4 times with $95 \% \mathrm{CI}=1.556-5.215$ and $1.939-8.914$ because the temperature has the potential to become a breeding place for mosquitoes. Unavailable wire net in ventilation is related to dengue transmission and raises the risk of a local outbreak of 6 times with $95 \% \mathrm{CI}=1.758-22.36$. Low lighting $<50$ lux meters is related to dengue transmission and raises the risk of a local outbreak by 6 times with $95 \% \mathrm{CI}=1.758-22.360$. The level of humidity in the house $>60 \%$ is related to dengue transmission and raises the risk of a local outbreak by 18 times with $95 \% \mathrm{CI}=$ 5.413 - 62.915. House environmental factors not significantly related to DHF transmission in Mataram City were conditions of floors, walls, temperature inside house, and humidity outside house. The existence and vector density factors of Aedes sp. with dengue transmission in Mataram City can be observed in three life cycles of mosquitoes, that are eggs, larvae and adult mosquitoes.

Entomology index in Mataram City based on WHO Density Figure. 21 exist on scale of $>6$ to $95 \%$ CI values at $30 \%$, scale 5 for house index (HI) values, this indicates that the current area in Mataram have a very high vector density and declared vulnerable to dengue infection. The description of the presence of eggs inside and outside the house from the number of ovitrap spread was found by mosquito eggs at $50.6 \%$ and $67.2 \%$. This value shows the level-1 classification. Description of the results of catching female Ae. aegypti mosquitoes in each part of the house showed any potential of mosquitoes for hunting prey and laying eggs, with an average catching result of one mosquito.

Table 2 shows that the existence of larvae is related to DHF transmission and raises the risk of a local outbreak of 3 times with $95 \% \mathrm{CI}=1.755-6.726$. Larva density $>21 \%$ is related to DHF transmission and raises the risk of a local outbreak of 2.7 times with $95 \% \mathrm{CI}=$ $1.132-6.646$. The existence of eggs at home is related to transmission of DHF and raises the risk of a local outbreak by 3 times with $95 \% \mathrm{CI}=1.704-5.752$. The

Table 1. Analysis of Home Environment Factors with Transmission of Dengue Hemorrhagic Fever

\begin{tabular}{|c|c|c|c|c|c|c|c|c|}
\hline \multirow{3}{*}{ Home Environmental } & \multirow{3}{*}{ Category } & \multicolumn{4}{|c|}{ Frequency } & \multirow{3}{*}{ OR } & \multirow{3}{*}{$95 \% \mathrm{CI}$} & \multirow{3}{*}{ p-value } \\
\hline & & \multicolumn{2}{|c|}{ Case } & \multicolumn{2}{|c|}{ Control } & & & \\
\hline & & $\mathbf{n}$ & $\%$ & $\mathbf{n}$ & $\%$ & & & \\
\hline \multirow[t]{2}{*}{ Flooring } & Plain ground & 6 & 6.7 & 3 & 3.3 & 2.07 & $0.502-8.552$ & 0.497 \\
\hline & Plastered/ tiled/ ceramics & 84 & 93.3 & 87 & 96.7 & & & \\
\hline \multirow[t]{2}{*}{ Wall } & Non-water resistant & 3 & 3.3 & 3 & 3.3 & 1.00 & $0.195-5.092$ & 1.000 \\
\hline & lastered, water resistant & 87 & 96.7 & 87 & 96.7 & & & \\
\hline \multirow[t]{2}{*}{ Ceiling } & None or in several room or $<2.5$ meters high & 58 & 64.4 & 9 & 10.0 & 16.31 & $7.237-36.769$ & $<0.001$ \\
\hline & Present in all room or $>2.5$ meters high & 32 & 35.6 & 81 & 90.0 & & & \\
\hline \multirow{2}{*}{ Ventilation } & No wire net & 87 & 96.7 & 74 & 82.2 & 6.27 & $1.758-22.360$ & 0.003 \\
\hline & Wire net installed & 3 & 3.3 & 16 & 17.8 & & & \\
\hline \multirow[t]{2}{*}{ Indoor air temperature } & Potential for Aedes $s p$. breeding & 58 & 64.4 & 35 & 38.9 & 2.85 & $1.556-5.215$ & 0.001 \\
\hline & Not Potential for Aedes $s p$. breeding & 32 & 35.6 & 55 & 61.1 & & & \\
\hline \multirow[t]{2}{*}{ Outdoor air temperature } & Potential for Aedes sp. breeding & 33 & 36.7 & 11 & 12.2 & 4.16 & $1.939-8.914$ & $<0.001$ \\
\hline & Not Potential for Aedes $s p$. breeding & 57 & 63.3 & 79 & 87.8 & & & \\
\hline \multirow[t]{2}{*}{ Indoor air temperature } & Potential in placing mosquito eggs & 3 & 3.3 & 7 & 7.8 & 0.41 & $0.102-1.634$ & 0.330 \\
\hline & Potential in placing mosquito eggs & 87 & 96.7 & 83 & 92.2 & & & \\
\hline \multirow[t]{2}{*}{ Light intensity } & Low $(<60$ Lux Meter $)$ & 50 & 55.6 & 9 & 10.0 & 11.25 & $5.033-25.149$ & $<0.001$ \\
\hline & High ( $\geq 60$ Lux Meter) & 40 & 44.4 & 81 & 90.0 & & & \\
\hline \multirow[t]{2}{*}{ Indoor humidity } & High $(>60 \%)$ & 35 & 38.9 & 3 & 3.3 & 18.45 & $5.413-62.915$ & $<0.001$ \\
\hline & Low $(\leq 60 \%)$ & 55 & 61.1 & 87 & 96.7 & & & \\
\hline \multirow[t]{2}{*}{ Outdoor humadity } & High $(>60 \%)$ & 27 & 30.0 & 24 & 26.7 & 1.18 & $0.616-2.256$ & 0.741 \\
\hline & Low $(\leq 60 \%)$ & 63 & 70.0 & 66 & 73.3 & & & \\
\hline
\end{tabular}

Notes: $\mathrm{OR}=$ Odds Ratio; $\mathrm{CI}=$ Confidence Interval 
Table 2. Analysis of Entomology Index with Transmission of Dengue Hemorrhagic Dengue

\begin{tabular}{|c|c|c|c|c|c|c|c|c|}
\hline \multirow{3}{*}{ Vector } & \multirow{3}{*}{ Category } & \multicolumn{4}{|c|}{ Frequency } & \multirow{3}{*}{ OR } & \multirow{3}{*}{$95 \% \mathrm{CI}$} & \multirow{3}{*}{ p-value } \\
\hline & & \multicolumn{2}{|c|}{ Case } & \multicolumn{2}{|c|}{ Control } & & & \\
\hline & & $\mathbf{n}$ & $\%$ & n & $\%$ & & & \\
\hline \multirow[t]{2}{*}{ Existence of larvae } & Yes & 40 & 44.4 & 17 & 18.9 & 3.44 & $1.755-6.726$ & $<0.001$ \\
\hline & No & 50 & 55.6 & 73 & 81.1 & & & \\
\hline \multirow[t]{2}{*}{ Density of larvae } & High risk $(>21 \%)$ & 19 & 21.1 & 8 & 8.9 & 2.74 & $1.132-6.646$ & 0.035 \\
\hline & Low risk/not risk $(\leq 21 \%)$ & 71 & 78.9 & 82 & 91.1 & & & \\
\hline \multirow[t]{2}{*}{ Indoor existence of eggs } & Yes & 58 & 64.4 & 33 & 36.7 & 3.13 & $1.704-5.752$ & $<0.001$ \\
\hline & No & 32 & 35.6 & 57 & 63.3 & & & \\
\hline \multirow[t]{2}{*}{ Outdoor existence of eggs } & Yes & 37 & 41.1 & 27 & 30.0 & 1.63 & $0.880-3.016$ & 0.161 \\
\hline & No & 53 & 58.9 & 63 & 70.0 & & & \\
\hline \multirow[t]{2}{*}{ Existence of adult mosquitoes } & Yes & 30 & 33.3 & 10 & 11.1 & 4.00 & $1.815-8.814$ & 0.001 \\
\hline & No & 60 & 66.7 & 80 & 88.9 & & & \\
\hline
\end{tabular}

Note: $\mathrm{OR}=$ Odds Ratio; $\mathrm{CI}=$ Confidence Interval

Table 3. Analysis of Physical Environment as Predictor Variables Related to Dengue Hemorrhagic Fever Transmission

\begin{tabular}{lrrrrr}
\hline & & & & \multicolumn{2}{c}{ 95\% CI for Exp ( $\boldsymbol{\beta})$} \\
\cline { 5 - 7 } Variable & $\boldsymbol{\beta}$ & Sig. & Exp $(\boldsymbol{\beta})$ & Lower & Upper \\
\hline Ceiling (none or in several room or $<2.5$ meters high) & 3.094 & $<0.001$ & 22.055 & 8.154 & 59.649 \\
Indoor air temperature to Potential for Aedes sp. breeding & 1.143 & 0.016 & 3.138 & 1.239 & 7.946 \\
Light intensity $(<60$ Lux Meter) & 2.314 & $<0.001$ & 10.113 & 3.508 & 29.149 \\
Indoor humadity to potential in placing mosquito eggs & 1.333 & 0.069 & 3.793 & 0.901 & 15.964 \\
\hline Constants & -2.612 & $<0.001$ & 0.073 & & \\
\hline
\end{tabular}

Note: $\beta=$ Coefficient Beta; Sig.= Significance; $\operatorname{Exp}(\beta)=$ Beta Exponential

existence of adult mosquitoes is related to DHF transmission and raises the risk of a local outbreak by 4 times with $95 \% \mathrm{CI}=1.815-8.814$. The factor of the existence of eggs found outside the home is not related to transmission of DHF in Mataram City.

Multivariate analysis was applied to determine the type of predictor variables of physical environmental factors associated with dengue transmission and that impact on local outbreaks. There were 6 variables in bivariate analysis with p-value $<0.25$ namely roof, ventilation, indoor and outdoor temperature, indoor humidity and light intensity. The analysis was complemented by a model quality test consisting of two stages, namely assessing the equality quality and the discrimination value. The model quality test results showed that environmental factors were declared feasible to predict dengue transmission in Mataram City. Forward Likelihood Ratio (LR) multiple logistic regression was applied, multi-collinearity was checked and not found, interaction was found, Hosmer Lemeshow test ( $p$-value $=0.914)$, area under the ROC curve $(91.3 \%)$ was applied to check the model fit.

The results of the multivariate analysis showed that the predictor variable of the physical environment of the house that affected the transmission of DHF was none or in several room or $<2.5$ meters high $(\mathrm{OR}=22.05)$, low house lighting $(\mathrm{OR}=10.11)$, indoor air temperature to potential for Aedes sp. breeding $(\mathrm{OR}=3.14)$ and low humidity in house $(<60 \%)(\mathrm{OR}=3.79)$ (Table 3$)$.

Multivariate analysis was to determine the type of predictor variables of entomology index with DHF transmission and which had an impact on local outbreaks. There were three variables in bivariate analysis with p-value $<0.250$ including existence of larvae, indoor existence of eggs and existence of adult mosquitoes (Table 4). The analysis was complemented by a model quality test consisting of two stages, namely assessing the equality quality and the discrimination value. The model quality test results show that environmental factors were declared feasible to predict dengue transmission in Mataram City. Forward LR multiple logistic regression was applied, multi-collinearity was checked and not found, Interaction was found, Hosmer Lemeshow test ( $\mathrm{p}$-value $=0.741$ ), area under the ROC curve $(77.5 \%)$ was applied to check the model fit.

The results of multivariate analysis showed that the dominant factors in the presence and vector density of Aedes $s p$. in the community affecting the transmission of DHF were the presence of Aedes sp. mosquito eggs in the house $(\mathrm{OR}=3.34)$, the presence of Aedes $s p$. 
Table 4. Analysis of Existence and Vector Density as Predictor Variables Related to Dengue Hemorrhagic Fever Transmission

\begin{tabular}{lccccc}
\hline Variable & $\boldsymbol{\beta}$ & Sig. & $\operatorname{Exp}(\boldsymbol{\beta})$ & \multicolumn{2}{c}{ CI 95\% for $\operatorname{Exp}(\boldsymbol{\beta})$} \\
\cline { 5 - 6 } & & & & Lower & Upper \\
\hline Existence of larvae & 0.971 & 0.012 & 2.641 & 1.237 & 5.639 \\
Indoor existence of eggs & 1.206 & 0.000 & 3.340 & 1.745 & 6.390 \\
Existence of adult mosquitoes & 1.008 & 0.025 & 2.741 & 1.137 & 6.606 \\
\hline Constants & -2.612 & 0.000 & 0.073 & & \\
\hline
\end{tabular}

Note: $\beta=$ Beta Coefficient; Sig.= Significance; $\operatorname{Exp}(\beta)=$ Beta Exponential

mosquitoes $(\mathrm{OR}=2.74)$, and the presence of Aedes $s p$. larvae $(\mathrm{OR}=2.64)$.

\section{Discussion}

From the preceding results, potential factors influencing occurrence of DHF in Mataram City were investigated further through observations made of the housing physical environment, existence and vector density

For house flooring, it is preferred to have plastered, or flooring made of tiles or ceramics in order to reduce room humidity, interrupting mosquito breeding cycle. ${ }^{22}$ Flooring of plain ground will turn damp during rainy season, hence creating more humid environment suitable for mosquito breeding. ${ }^{23}$ Similarly, plastered walls are also preferred, so that dengue-carrying mosquitoes cannot enter the house through small holes in the walls. ${ }^{24}$ In this study, over $80 \%$ of total surveyed households, both in case and control groups have already owned houses with plastered flooring and walls. This may explain non-association between those factors and DHF occurrence in the study population.

The presence of windows, doors, roofs, and ventilation were thought to be associated with dengue virus transmission in home environment. ${ }^{25}$ The current study results showed that over $75 \%$ of the total surveyed households had bedroom windows and doors in all the rooms. The presence of doors and windows may result in two different outcomes, namely reduced mosquito density due to reduced humidity and increased light intensity, or increased mosquito density due to presence of more entryways for mosquitoes to enter the house when they are left opened. ${ }^{13,26}$ However, these two factors did not demonstrate association with DHF occurrence in the present study. The presence of ventilations may also have similar outcomes, if the ventilations were not installed with wire nets. The use of wire nets on ventilations for control group reached $96.7 \%$ higher than the case group at $82.2 \%$ of the total observed houses. Wire nets installed in ventilations, doors, and windows may act as barriers for mosquitoes to enter the house, preventing them to rest and to bite residing humans inside. ${ }^{27}$ Absence of roof may facilitate the entry of mosquitoes in houses. ${ }^{28}$ Most houses in Mataram City do not have a barrier between the upper wall and the roof of the house. This condition is not much different from a house that has a cracked and hollow roof. The presence or the height of ceilings $>2.5$ meters in control group was at $64.4 \%$ higher than the case group at $10 \%$.

In addition, temperature, lighting, and humidity affect mosquito bionomics as well, particularly feeding behavior and mosquito development. In the present study, humidity and temperature indoor and outdoor in the case and control groups stated differently, and both did demonstrate association with the occurrence of DHF case. Environment with a temperature of $25-27^{\circ} \mathrm{C}$ is optimal for Ae. aegypti larvae development, 29,14 and the time required for mosquitoes to fully develop from egg to adult depends on this range of température. 30,31 Increased temperature may result in shorter time needed for mosquito development, hence increasing mosquito density and risk in transmitting dengue virus. ${ }^{32}$ Conversely, a humidity of less than $60 \%$ causes shorter mosquito life span, decreasing their vectoral capacity as dengue vectors. ${ }^{14}$ Most home lighting in DHF patients is $<60$ lux, so it has a risk of DHF. Light intensity is the biggest factor that affects mosquito flight activities because low light and high humidity are good conditions for mosquitoes. Ae. aegypti mosquitoes like to rest in rather dark places in damp spaces with low light intensity. ${ }^{33}$ Mosquitoes are likely to rest inside house because the female Ae. aegypti never fly far away from the place the eggs are laid. ${ }^{13}$ Most of the rooms can be a comfortable resting place for mosquitoes, such as bedroom, living room, family room, kitchen to bathroom as long as they meet the requirements (dark and humid) as a place for mosquitoes. ${ }^{34}$

Measurement of larvae density levels is used to suppress the spread of dengue disease and reduce the economic and public health impacts, through a specific strategy that is to reduce mosquito breeding places to dengue vectors with bretau index $(\mathrm{BI})<5 \%$ and house index $(\mathrm{HI})<1 \% .35$ Based on these indicators, it can be 
interpreted that Mataram City can be considered as a medium-to-high-risk area for the spread of dengue disease and has the potential to experience local outbreaks in several areas.

The high density and presence of larvae, eggs and mosquitoes were related to dengue fever in the city of Mataram. This condition was because not all communities actively participated in implementing Mosquito Nest Eradication properly. In this study, Ae. aegypti mosquitoes were found in bathtubs or toilets, hence according to them, it was very impractical if the bath had to be closed. The observation results in most of the respected houses found by larvae did not have good lighting in the bathroom, thus the cadre examination process was not carried out carefully and there was still an assumption that Ae. aegypti mosquitoes could not breed in clean water. The conditions are in accordance with the results of ra study in Sleman, Yogyakarta that the cadres activeness and accuracy in monitoring their environment are very important to prevent an increase in dengue cases. ${ }^{36}$ Some people throw garbage in the garden and do not dispose regularly once a week, so that mosquitoes are suspected of having the opportunity to lay eggs. The implementation of this study was carried out during the rainy season, therefore, the chances of used containers filled with water were found in the yard and gardens near residential areas.

The emergence of dengue cases is caused by ineffective controls, uncontrolled population mobility, limited health infrastructure and the use of different larva indicators. 37 The entomology index (house index, building index, container index) is very influential on the value of numbers of Larva Free Index, the higher the entomology index, the lower the numbers of Larva Free Index value. Numbers of Larva Free Index that has not reached the standard indicates that the area still has the potential for dengue fever because numbers of Larva Free Index is one of the epidemiological measures often used in dengue control activities, one of which is by conducting a larva survey. ${ }^{3}$ This is consistent with study in Tamil Nadu District, India for an early warning system of dengue epidemic that needs to be carried out by larvae surveillance. Larva surveillance is not only to determine larvae density, but also to predict transmission by monitoring mosquito-breeding sites. ${ }^{38}$

\section{Conclusion}

Physical environmental factors, such as the unavailable ceiling, indoor and outdoor temperature have the potential as mosquito-breeding places. Unavailable wire net on ventilation, low lighting, and high humadity are related to DHF transmission. Vector distibution with entomology index shows the exixtence of larvae, eggs and mosquitoes play a role in dengue transmission. The dominant factors affecting the transmission of dengue in Mataram City are the condition of the ceiling and the existence of mosquito eggs in the house.

The Mataram City Health Office and all primary health care need to improve monitoring of larvae survey activities carried out by larva monitors and the $3 \mathrm{M}$ plus (draining, covering, burying or utilizing/recycling, and terminating larvae) movement in the community. This program greatly assists the process of monitoring the implementation of disease control program and is capable of breaking the cycle of vector breeding at an early stage. A program to measure egg density that has the potential for outbreaks can be developed as an effective DHF control effort in the community environment. This activity also needs to be supported by providing education to the community about the healthy physical environment of the house, so that it can reduce the risk of dengue transmission which has an impact on local outbreaks.

\begin{abstract}
Abbreviations
SEARO: South-east Asia Regional Office; DHF: Dengue hemmorhagic fever; IR: Incidence rate; CFR: Case fatality rate; PE: Penyelidikan Epidemiologi (Epidemiological Investigation); AUC: Area under curve; ROC: Receiver operating curve; LR: Likelihood ratio; HI: House Index; 3M: Menguras, Menutup, Mengubur (draining, covering, burying or utilizing/recycling); BI: Bretau Index.
\end{abstract}

\section{Ethics Approval and Consent to Participate}

This study is part of a study approved for ethics by the Faculty of Health Science, Respati University of Yogyakarta, with Protocol Number: 167.1/UNRIYO/PL/VII/2018 on July 2018.

\section{Competing Interest}

Author declares that there are no significant competing financial, professional, or personal interests that might have affected the performance or presentation of the work described in this manuscript.

\section{Availability of Data and Materials}

The data that support the findings of this study are available from the corresponding author upon reasonable request.

\section{Authors' Contribution}

All Authors conceived of the presented idea in this manuscript. Tri B T Satoto, Tri Wibawa: developed the theory; Nur Alvira Pascawati: analysed data and co-wrote the manuscript; Tri Wibawa, Roger Frutos: verified the analytical methods; Sylvie Maguin: ensure the observation procedure of research variables; I Kadek Mulyawan: verify the data from home environment observations; Ali Wardana: investigate entomology index in community and and identify vectors based on species. Tri B T Satoto, Nur Alvira Pascawati: supervised the findings of this work. All authors discussed the results and contributed to the final manuscript. Nur Alvira Pascawati, Tri B T Satoto: wrote the manuscript with support from Tri Wibawa, Roger Frutos, Sylvie Maguin, I Kadek 
Mulyawan, and Ali Wardana.

\section{Acknowledgment}

The authors are deeply grateful for the 2018 Research Grant from Ministry of Education and Research of Indonesia Funds No 1667/UN1/DITLIT/DIT-LIT/LT/2018. Gratitude is also directed towards local health volunteers, field surveyors, and laboratory technicians, without them the study would not have been conducted well.

\section{Additional Information}

Tri B T Satoto ${ }^{1}$, Nur Alvira Pascawati ${ }^{*}$, Tri Wibawa ${ }^{3}$, Roger Frutos ${ }^{4}$, Sylvie Maguin ${ }^{4}$, I Kadek Mulyawan ${ }^{5}$, Ali Wardana 6.

${ }^{1}$ Department of Parasitology, Faculty of Medicine, Gadjah Mada University, Yogyakarta, Indonesia; 2 Public Health Studies Program, Faculty of Health Science, Respati University, Yogyakarta, Indonesia; ${ }^{3}$ Department of Microbiology, Faculty of Medicine, Gadjah Mada University, Yogyakarta, Indonesia; ${ }^{4}$ University of Montpellier, Montpellier, France; ${ }^{5}$ Department of Health Center, Mataram City, Indonesia; ${ }^{6} \mathrm{Health}$ Training Center, West Nusa Tenggara, Indonesia

\section{References}

1. Brady OJ, Gething PW, Bhatt S, Messina JP, Brownstein JS, Hoen AG, et al. Refining the global spatial limits of dengue virus transmission by evidence-based consensus. PLoS Neglected Tropical Disease. 2012; 6(8): e1760.

2. Bhatt S, Gething PW, Brady OJ, Messina JP, Farlow AW, Moyes CL, et al. The global distribution and burden of dengue. Nature. 2013; 496(7446): 504-7.

3. Sariwati. Seminar Nasional: pengendalian penyakit tular vektor. Yogyakarta; 2017.

4. Dinas Kesehatan Kota Mataram. Profil Kesehatan Kota Mataram Tahun 2016; 2016.

5. Khan J, Khan I, Ghaffar A, Khalid B. Epidemiological trends and risk factors associated with dengue disease in Pakistan (1980-2014): a systematic literature search and analysis. PMC Public Health. 2018; 18 : 745.

6. Masyeni S, Yohan B, Somia IKA, Myint KSA, Sasmono RT. Dengue infection in international travellers visiting Bali, Indonesia. Journal of Travel Medicine. 2018; 25(1): 1-7.

7. Åström, Christofer Rocklöv, Joacim Hales, Simon Béguin A, Louis, Valerie Sauerborn R. Potential distribution of dengue fever under scenarios of climate change and economic development. Ecohealth. 2012; 9(4): 448-54.

8. Cromwell et al. The relationship between entomological indicators of Aedes aegypti abundance and dengue virus unfection. PLOS Neglected Tropical Diseases. 2017; 11(3): e0005429.

9. Widiastuti D, Kesuma AP, Pramestuti N. Entomological index and transovarial transmission contribute to Dengue Haemorrhagic Fever outbreaks in Banjarnegara Regency. Spirakel. 2016; 8(1): 30-7.

10. Nadifah F, Farida Muhajir N, Arisandi D, D. Owa Lobo M. Identifikasi larva nyamuk pada tempat penampungan air di Padukuhan Dero Condong Catur Kabupaten Sleman. Jurnal Kesehatan Masyarakat Andalas. 2017; 10 (2): 172-178.
11. Pohan NR, Alvira N, Wati P, Nurhadi M. Gambaran kepadatan dan tempat potensial perkembangbiakan jentik Aedes sp. di tempat-tempat umum wilayah kerja Puskesmas Umbulharjo 1 Kota Yogyakarta. Jurnal Formil (Forum Ilmiah) KesMas Respati. 2016; 1(2): 109-20.

12. Astuti, Lustiyati ED. Hubungan kondisi lingkungan fisik terhadap tingkat kepadatan larva Aedes sp di Sekolah Dasar Kecamatan Bantul, DIY. Jurnal Ilmu Kesehatan Masyarakat. 2018; 9(3): 216-225.

13. Satoto TBT, Alvira N, Wibawa T, Diptyanusa A. Improvement to Early warning system the transmission of Dengue Fever through controlling potential factor in Public Elementary School at Yogyakarta. Kesmas: National Public Healh Journal. 2017; 11(4): 178-84.

14. Pascawati NA, Baskoro T, Satoto T, Wibawa T, Frutos R, Maguin S. Potential impact of climate change on dhf dynamics transmission in Mataram City. BALABA. 2019; 15(1): 49-60.

15. Wanti, Yudhastuti R, Notobroto HB, Subekti S, Sila O, Ragu, Febi. Dengue haemorrhagic fever and house conditions in Kupang City, East Nusa Tenggara Province. Kesmas National Public Health Journal. 2019; 13(4): 176-81.

16. Getachew D, Tekie H, Michael TG, Balkew M, Mesfin A. Breeding sites of Aedes aegypti: potential dengue vectors in Dire Dawa East Ethiopia. Interdisciplinary Perspectivas on Infectious Diseases. 2015; 706276: 1-8.

17. Viennet E, Scott, Craig, Williams, Helen, David. Public health responses to and challenges for the control of dengue transmission in high-income countries: case studies. PLOS Necgelted Tropical Diseases. 2016 September 19; 10(9): e0004943.

18. Dinas Kesehatan Kota Mataram. Laporan kasus DBD per tahun. Mataram; 2018.

19. Ghozali. Analisis multivariat program. Semarang: UNDIP; 2013.

20. Sopiyudin D. Statistika untuk kedokteran dan kesehatan. Jakarta: Salemba Medika. 2017; 1-181p.

21. Iriani Y. Hubungan antara curah hujan dan peningkatan kasus Demam Berdarah Dengue anak di Kota Palembang. Sari Pediatri. 2012;13(6): 378-83.

22. Centers for Disease Control and Prevention. Healthy housing reference manual. Atlanta: Department of Housing and Urban Development; 2017.

23. Day J. Mosquito oviposition behavior and vector control. Insects. 2016; 7(4): 65.

24. Powell JR, Tabachnick WJ. History of domestication and spread of Aedes aegypti--a review. Memorias do Insituto Oswaldo Cruz. 2013; 108 Suppl 1: 11-17.

25. Baskoro T, Satoto T, Diptyanusa A, Setiawan YD, Alvira N. Environmental factors of the home affect the density of Aedes aegypti (Diptera: Culicidae). YARSI. 2017; 25(1): 41-51.

26. Snyman, Florence, Victor, James, Tamara, Beth, Bryan, Hugh, Roly, Jenny, Grant. Poor housing construction associated with increased malaria incidence in a cohort of young ugandan children. American Journal Tropical Medicine and Hygiene. 2015; 92(6):1207-1213.

27. Kampango A, Bragança M, Sousa B de, Charlwood JD. Netting barriers to prevent mosquito entry into houses in southern Mozambique: a pilot study. Malaria Journal. 2013; 12(1): 99.

28. Baskoro T, Dwiputro AH, Risdwiyanto RN, Fadli UA, Alvira, Diptyanusa. Prediction model of dengue hemorrhagic fever transmis- 
sion to enhance early warning system in Gergunung Village Klaten District Central Java. Journal of the Medical Science. 2019; 51(3): 258-69.

29. Reinhold JM, Lazzari CR, Lahondere C. Effects of enviromental temperature on Aedes aegypti: a Review. Insects. 2018; 9(4): 158.

30. Mohammed A, Chadee DD. Effects of different temperature regimens on the development of Aedes aegypti (L.) (Diptera: Culicidae) mosquitoes. Acta Tropical. 2011; 119(1): 38-43.

31. Muturi EJ, Blackshear M, Montgomery A. Temperature and densitydependent effects of larval environment on Aedes aegypti competence for an alphavirus. Journal Vector Ecolocy. 2012; 37(1): 154-61.

32. Costa EAP de A, Santos EM de M, Correia JC, Albuquerque CMR de. Impact of small variations in temperature and humidity on the reproductive activity and survival of Aedes aegypti (Diptera, Culicidae). Revista Brasileira de Entomologia. 2010; 54(3): 488-93.

33. Nurdiana Hayu, Trixie Salwati RA. Kejadian demam berdarah dengue berdasarkan faktor lingkungan dan praktik pemberantasan sarang nya- muk di wilayah kerja Puskesmas Srondol, Kecamatan Banyumanik, Semarang. Jurnal Kesehatan Masyarakat Indonesia. 2010; 6(1): 57-66. 34. Sari E, Wahyuningsih NE, Murwani R. Hubungan lingkungan fisik rumah dengan kejadian Demam Berdarah Dengue di Semarang. Jurnal Kesehatan Masyarakat Indonesia. 2017; 5(1): 609-18.

35. Wati NAP. Survei entomologi dan penentuan maya index di daerah endemis DBD di Dusun Krapyak Kulon Desa Panggungharjo Kecamatan Sewon Kabupaten Bantul DIY. Medica Respati. 2015; 10(3): 76-86.

36. Astuti FD, Susanti A. Perbedaan indeks entomologi pemantauan jumantik dewasa dan jumantik anak di Dusun Mejing Kidul, Ambarketawang, Gamping, Sleman, Yogyakarta. Jurnal Vektor Penyakit. 2017; 11(1): 33-42.

37. Anthony MC, Cook ADB, Amul GGH, Sharma A. Health governance and dengue in Southeast Asia. NTS Report. 2015; 2: 12-6.

38. Bhat MA, Krishnamoorthy K, Khan AB. Entomological surveillance of Dengue vectors in Tamil Nadu, India. Journal Entomology Zoology Studies. 2014; 2(6): 158-64. 